\title{
IN MEMORIAM MANFRED LACHS
}

When Manfred Lachs died I lost more than a friend.

Vividly I remember the day -now nearly twenty years ago-he stepped into my room at the Foreign Office. He was announced as "His Excellency Judge Lachs, President of the International Court of Justice". According to the strict rules of protocol I think he should not have come to me but instead have asked me to come to his office, he being the President of the highest judicial organ of the international community, me a mere State Secretary of one of the member-states, be it the host-state. But if a problem was bothering him, he was willing to go to the ends of the earth to solve it and at that time something was seriously bothering him.

The World Court was considering the possibility of moving out of The Hague as a number of its members were dissatisfied with the conditions under which they had to carry out their function; relations between the Court and the host-Government had been strained for some years and the possible transfer of the Court's seat had been placed on the agenda of the General Assembly. Those who know Manfred Lachs also know that strained relations were not much to his liking. But -and that is even more important- he was of the opinion that moving the Court from its long-established base would ultimately damage the Court. It should not be forgotten that the Court had barely recovered from the profound loss of esteem it had suffered as the result of its decision in the South West Africa case of July 18, 1966. This esteem had been regained to a certain extent by the famous obiter dictum in the Barcelona Traction case on obligations erga omnes and by the advisory opinion on Namibia but, nevertheless, the Court's reputation was still vulnerable. Moving the Court away from The Hague could entail various risks for the Court, which he all discussed with me. If there was one thing which mattered in this world for Manfred Lachs, professionally speaking, it was the Court and at that moment he was President of that Court and that gave an extra dimension to his concern.

Together with the then foreign Minister we were able to solve all problems and the Court stayed at The Hague. But as the present Minister of Foreign Affairs of the Netherlands, I wish to say that it is to a great extent due to Manfred Lachs that these problems could be solved and that the item of the seat of the World Court could be removed from the General Assembly's agenda. His straightforwardness, his openness, his integrity and his fairness were of great help. Although he loved The Hague and the Netherlands, it was not his love for this country but his deep love for the Court which prompted him to try to keep the Court in The Hague.

This common experience made us friends. But Judge Lachs came to see me more often than was necessary for consultations on the issue of the Court's seat in those days. There was another problem which troubled him deeply and again it was love for the Court which moved him. The Nuclear Tests cases were pending before the Court; by applying the law strictly and basing itself faithfully on the closed categories of formal sources of law, the Court could easily -and from a legal point of view not incorrectlyhave come to the conclusion that there was no legal impediment for France to continue to carry out its nuclear atmospheric tests. But maybe more than anybody else, Manfred Lachs was aware of the devastating effects such a decision could have for the reputation of the Court, as the General Assembly had pleaded in numerous resolutions 
for a discontinuance of such tests. Esteem for the Court in the international community could plummet to a new low. He realised that a repetition of 1966 could be fatal for the Court and as the Court's President he hoped to avoid such an outcome. So he looked for other venues but he wanted to try them out first. He needed a sounding board and because of the friendship which had grown between us, I happened to be that sound board. During numerous get-to-gethers, luncheons etc. he argued and asked for my reactions and, although I never was sure which outcome he really wanted, during these conversations my admiration and respect grew; I had not only found a friend, but -even more important- a tutor, a guru. During these conversations I looked with new eyes at law as a social phenomenon. I learned to understand the function of law not only as a conservating element but also as a vehicle for change.

The final decision of the Court has been severely criticized; nevertheless I think that Mc Whinney is right when he says that it was historically correct and necessary. And, in a tribute for Manfred Lachs, he adds:

The Judgment is recognisably from Judge Lachs' pen and stands as an exercise in judicial pragmatism by a Court President trying carefully to build a majority among judges, who were then even more cautious then today, as to venturing on the avant-garde in doctrinal-legal terms (into law making through jurisprudence).

During these conversations I learned to recognize judicial wisdom. Years later I gave a course on judicial wisdom and legal reasoning in international adjudication for the Hague Academy. Then I said:

Legal reasoning unaccompanied by judicial wisdom may lead to a decision that is legally correct but in actual life is an application of the maxim "let justice be done though the sky falls". Judicial wisdom without accurate and sound legal reasoning is judicial folly, for it will impair the confidence in the legal system and in the judicial system as such. Judicial wisdom, therefore, is nothing more less than making the socially correct choice between various applications of legal rules on a concrete case.

After the first lecture a student came to me and asked me whether I could give a definition of judicial wisdom. Judge Lachs was standing in a corner of the room, talking, as usual, with students as he liked to do. I told the student that I could not give him a definition, that I hoped that he would be able to recognize judicial wisdom after the last lecture but that I could show him its personification and I pointed to Judge Lachs.

Because that is how I will remember him most; as the personification of judicial wisdom, permanently driven by his love for the Court, his love for justice and, therefore mostly striking the right balance; a legal scholar through and through but at the same time aware of the demands and the needs of society. "More perhaps than any other Member of the Court", Mc Whinney says,

Judge Lachs is seen as personifying the new judicial thinking, with its renouncing of the 'dead-hand control' of old doctrines and old jurisprudence developed in other, earlier times, in favour of rational contemporary solutions to contemporary problems of the world community. 
We are used to think of world leaders in terms of politicians and the high and the mighty. Manfred Lachs was a world leader in his own right. When he died we lost more than a friend.

Prof. P.H. Kooijmans*

* Minister for Foreign Affairs of The Netherlands 